\section{Predictors of recovery following allogeneic CD34'-selected cell infusion without conditioning to correct poor graft function}

\author{
Maria M. Cuadrado, ${ }^{1}$ Richard M. Szydlo, ${ }^{1,2}$ Mike Watts, ${ }^{3}$ Nishil Patel, ${ }^{4}$ Hanna \\ Renshaw, ${ }^{4}$ Jude Dorman, ${ }^{5}$ Mark Lowdell, ${ }^{6}$ Stuart Ings, ${ }^{3}$ Chloe Anthias, ${ }^{1}$ \\ Alejandro Madrigal, ${ }^{1}$ Stephen Mackinnon, ${ }^{5}$ Panagiotis Kottaridis, ${ }^{5}$ Ben \\ Carpenter, ${ }^{5}$ Rachael Hough, ${ }^{5}$ Emma Morris, ${ }^{5}$ Kirsty Thomson, ${ }^{5}$ Karl S. Peggs ${ }^{5,7}$ \\ and Ronjon Chakraverty ${ }^{5,7}$
}

${ }^{1}$ Anthony Nolan Research Institute; ${ }^{2}$ Department of Haematology, Imperial College London; ${ }^{3}$ Wolfson Cellular Therapy Unit, University College Hospital London NHS Trust; ${ }^{4}$ Department of Haematology, Royal Free London NHS Trust; ${ }^{5}$ Department of Haematology, University College Hospital NHS Trust; ${ }^{6}$ Centre for Cell, Gene \& Tissue Therapeutics, Royal Free London NHS Trust and 'Department of Hematology, Cancer Institute, University College London, London, UK

\section{ABSTRACT}

$\mathrm{P}$ oor graft function is a serious complication following allogeneic hematopoietic stem cell transplantation. Infusion of CD34-selected stem cells without pre-conditioning has been used to correct poor graft function, but predictors of recovery are unclear. We report the outcome of 62 consecutive patients who had primary or secondary poor graft function who underwent a CD34+-selected stem cell infusion from the same donor without further conditioning. Forty-seven of 62 patients showed hematologic improvement and became permanently transfusion- and growth factorindependent. In multivariate analysis, parameters significantly associated with recovery were shared cytomegalovisur seronegative status of both the recipient and donor, the absence of active infection and matched recipientdonor sex. Recovery was similar in patients with mixed and full donor chimerism. Five-year overall survival rates were $74.4 \%$ (95\% confidence interval [95\% CI: 59-89]) in patients demonstrating complete recovery, $16.7 \%$ (95\% CI: $3-46$ ) in patients with partial recovery and 22.2\% (CI 95\% $5-47)$ in those who had no response. In patients with blood count recovery, those with poor graft function in one or two lineages had a better 5-year overall survival (93.8\%, 95\% CI: 82-99) than those with trilineage failure (53\%, 95\% CI: 34-88). New strategies including cytokine or agonist support, or a second transplant need to be investigated in patients whose blood counts do not recover.

\section{Introduction}

Graft failure is a severe complication of allogeneic hematopoietic stem cell transplantation (SCT), which is associated with reduced survival, especially in patients being treated for hematologic malignancies. ${ }^{1,2}$ Graft failure caused by rejection is relatively uncommon with an incidence of $4-6 \%^{3}$ and ensues as a result of an antidonor response triggered by recipient $\mathrm{T}$ cells or NK cells or by pre-existing donorspecific antibodies (e.g., directed against human leukocyte antigens). Graft failure in the absence of rejection or tumor relapse is more common, with an incidence reported to be between $5-27 \%,{ }^{4}$ and is referred to as poor graft function. In practice, graft rejection and poor graft function can be distinguished by measuring chimerism: donor cells are undetectable in the former but persist in the latter. ${ }^{5}$ Multiple risk factors are associated with poor graft function including issues related to the donor (low stem cell dose and $\mathrm{ABO}$ blood group incompatibility), the type of conditioning (reduced intensity or nonmyeloablative conditioning) or the patient (primary diseases such as aplastic anemia or myelofibrosis, viral infections, drugs or the presence of graft-versus-host disease [GvHD]]., ${ }^{1,3}$

Currently, there are no clear recommendations for the treatment of poor graft

Ferrata Storti Foundation

Haematologica 2020
Volume 105(11):2639-2646

\section{Correspondence:}

RONJON CHAKRAVERTY

r.chakraverty@ucl.ac.uk

Received: May 16, 2019.

Accepted: November 20, 2019.

Pre-published: November 21, 2019.

doi:10.3324/haematol.2019.226340

(C)2020 Ferrata Storti Foundation

Material published in Haematologica is covered by copyright. All rights are reserved to the Ferrata Storti Foundation. Use of published material is allowed under the following terms and conditions:

https://creativecommons.org/licenses/by-nc/4.0/legalcode. Copies of published material are allowed for personal or internal use. Sharing published material for non-commercial purposes is subject to the following conditions: https://creativecommons.org/licenses/by-nc/4.0/legalcode, sect. 3. Reproducing and sharing published material for commercial purposes is not allowed without permission in writing from the publisher. 
function. Supportive care including growth factors and blood products are routinely administered but the latter can be associated with allo-immunization and transfusion-related iron overload. Other approaches, including the use of thrombopoietin-receptor agonists, are currently being investigated in early phase clinical trials. Second allogeneic SCT or infusions of unmanipulated peripheral blood stem cells are other options but are associated with a high risk of GvHD and non-relapse mortality. ${ }^{6}$ Larocca et al. ' reported on the use of CD34+-selected stem cell infusions from the original donor without conditioning for correction of poor graft function based on the premise that the risk of GvHD would be low. Clinical outcomes were favorable when compared to those of historical cohorts of patients who were given either no treatment or unmanipulated bone marrow/peripheral blood stem cells without pre-conditioning. Several recent series of patients administered CD34+-selected stem cell infusions have also shown promising results with an improvement of graft function reported in $72-81 \%$ of patients (Online Supplementary Table S1). ${ }^{8 \cdot 11}$ Although these studies were very important in establishing the principle of $\mathrm{CD}_{34} 4^{+}$ selected cells in the management of poor graft function, the small number of patients and heterogeneity, in terms of definitions of poor graft function or response, have made it difficult to predict which patients will benefit most from this treatment. Some studies excluded patients with GvHD, with active infection or use of myelosuppressive drugs, although in practice it is often difficult to determine the relative effect of such factors on the graft. Furthermore, all the studies to date have excluded patients with significant mixed chimerism, a group with increasing prevalence given the frequent use of reduced intensity conditioning and T-cell depletion. Thus, there is a need to identify predictors of response in clinically relevant populations of patients to ensure both suitable resource allocation and appropriate requests for repeat donor harvesting.

Here we report the outcome and analysis of predictors of recovery in 62 consecutive patients with poor graft function who were treated with donor $\mathrm{CD} 34^{+}$-selected infusion without conditioning. While the majority of patients had complete or partial recovery, cytomegalovirus (CMV) seropositivity, donor-recipient sex mismatching and active infection were all associated with inferior outcomes. Thus, our findings demonstrate the overall feasibility of the approach but also indicate that new strategies are still required in some groups of patients.

\section{Methods}

\section{Definitions}

Engraftment was defined as the first of 3 consecutive days when the absolute neutrophil count was $\geq 0.5 \times 10^{9} / \mathrm{L}$ and the absolute platelet count was $\geq 20 \times 10^{9} / \mathrm{L}$ with or without the administration of granulocyte colony-stimulating factor and without transfusion. Primary poor graft function was defined by: (i) failure to ever achieve count recovery in at least one lineage (neutrophils $\geq 0.5 \times 10^{9} / \mathrm{L}$, platelets $\geq 20 \times 10^{9} / \mathrm{L}$ and hemoglobin $\geq 8$ $\mathrm{g} / \mathrm{dL}$ in the absence of transfusion) after transplantation; (ii) a hypoplastic bone marrow; (iii) the absence of relapse; and (iv) the presence of donor cells as detected by peripheral blood chimerism studies. Secondary poor graft function was defined as for primary poor graft function with the exception that blood counts fell in at least one lineage after the initial achievement of engraftment. Recovery was categorized as complete or partial. Complete recovery was defined as a hematological improvement in all three cell lineages (hemoglobin $\geq 8 \mathrm{~g} / \mathrm{dL}$, platelets $\geq 30 \times 10^{9} / \mathrm{L}$ and neutrophils $\geq 1.5 \times 10^{9} / \mathrm{L}$ ) without the need for transfusion or growth factor support. Partial recovery was defined as a hematologic improvement in one or two lineages. Acute GvHD after CD34+-selected infusion was defined according to the criteria of Glucksberg et al., ${ }^{12}$ and chronic GvHD was defined as mild, moderate or severe, following the National Institutes of Health consensus criteria. ${ }^{13}$ Active infection was identified using the surrogate of parenteral antimicrobial therapy at the time of $\mathrm{CD} 34^{+}-$ selected infusion.

\section{Patients}

Between 1999-2018, 1996 allogeneic SCT were performed at University College Hospital and Royal Free Hospital in London, UK (Table 1). Seventy patients who received CD34+-selected infusions were identified; eight patients were excluded from the analysis because of disease relapse. This research project was considered by the NHS Health Research Authority as a nonResearch Ethics Committee study and was conducted in line with the harmonized UK-wide edition of the Governance Arrangements for Research Ethics Committees (GAfREC) 2018 and the UK Policy Framework for Health and Social Care Research (2017).

\section{Chimerism analysis}

Chimerism was analyzed by fluorescence in situ hybridization using the XX/XY dual color probe in whole blood or by lineagespecific chimerism using polymerase chain reaction analysis of informative minisatellite regions (short tandem repeat loci), as previously described,$^{14}$ within 60 days prior to CD34-selected infusion. This information was available for $87 \%$ of patients. Mixed chimerism of individual cell fractions was defined as the co-existence of donor and recipient DNA with the detection limit being $1-5 \%$ according to the individual short tandem repeat marker and the combination of homozygosity versus heterozygosity for each marker between donor and patient. Full donor chimerism was defined as the absence of detectable donor DNA in the relevant cell fraction using these sensitivity thresholds.

\section{CD34+ stem cell selection}

$\mathrm{CD} 34^{+}$cells were selected from peripheral blood stem cells that had been mobilized into the periphery by granulocyte colonystimulating factor using the CliniMACS CD34 enrichment system (Miltenyi Biotec GmbH, Germany) ${ }^{15}$ (Online Supplementary Comment 1). The CD34+-selected cells were infused within $24 \mathrm{~h}$ of selection and without cryopreservation. In six patients with mixed chimerism, a fixed dose of $\mathrm{T}$ cells (median $\mathrm{CD}^{+}$dose of $1 \times 10^{6}$, range $1 \times 10^{6}-1 \times 10^{8}$ ) was administered at the time of the $\mathrm{CD} 34^{+}$-selected cell infusion.

\section{Statistical analysis}

Recovery was compared between categorical variables using the $\chi^{2}$ test or Fisher exact test as appropriate, and between continuous variables using the Mann-Whitney $U$ test. Variables for which significant differences were found in univariate analyses were entered into a logistic regression analysis with a forward stepping procedure to find the best model. Probabilities of overall survival were calculated using the Kaplan-Meier method and groups compared with the log-rank test. Probabilities of recovery were estimated using the cumulative incidence procedure, and groups compared using Gray's test. SPSS version 24.0 (IBM SPSS Statistics for Windows, version 24.0. IBM Corp, Armonk, NY, USA) and $\mathrm{R}$ version $3.4 .2{ }^{16}$ were used for all analyses. 
Table 1. Allogeneic stem cell transplant characteristics.

\begin{tabular}{|c|c|}
\hline Characteristics & N. of patients (\%) \\
\hline Number & 62 \\
\hline Recipient age, median (range), years & $49(10-66)$ \\
\hline $\begin{array}{l}\text { Recipient sex } \\
\text { Male } \\
\text { Female }\end{array}$ & $\begin{array}{l}35(57 \%) \\
27(43 \%)\end{array}$ \\
\hline $\begin{array}{l}\text { Disease } \\
\text { Lymphoproliferative disorder } \\
\text { Acute myeloid leukemia } \\
\text { Acute lymphoblastic leukemia } \\
\text { Myelodysplastic syndrome } \\
\text { Severe aplastic anemia } \\
\text { Primary myelofibrosis } \\
\text { Primary immunodeficiency } \\
\text { Chronic myeloid leukemia } \\
\text { Sickle cell disease }\end{array}$ & $\begin{array}{c}30(48 \%) \\
11(18 \%) \\
7(11 \%) \\
5(8 \%) \\
3(5 \%) \\
2(3 \%) \\
2(3 \%) \\
1(2 \%) \\
1(2 \%)\end{array}$ \\
\hline $\begin{array}{l}\text { EBMT Risk Score* } \\
\text { Early disease stage } \\
\text { Intermediate disease stage } \\
\text { Late stage disease } \\
\text { Not applicable (non-malignant disease) }\end{array}$ & $\begin{array}{l}19(31 \%) \\
28(45 \%) \\
9(14 \%) \\
6(10 \%)\end{array}$ \\
\hline $\begin{array}{l}\text { HCT-CI } \\
\text { Low risk } \\
\text { Intermediate risk } \\
\text { High risk }\end{array}$ & $\begin{array}{c}45(73 \%) \\
15(24 \%) \\
2(3 \%)\end{array}$ \\
\hline $\begin{array}{l}\text { Donor type } \\
\text { Related donor } \\
\text { Matched unrelated donor } \\
\text { Mismatched unrelated donor }\end{array}$ & $\begin{array}{l}28(45 \%) \\
18(29 \%) \\
16(25 \%)\end{array}$ \\
\hline $\begin{array}{l}\text { CMV status (R/D) } \\
\text { Negative/negative } \\
\text { Other }\end{array}$ & $\begin{array}{l}23(37 \%) \\
39(63 \%)\end{array}$ \\
\hline $\begin{array}{l}\text { ABO status (R/D) } \\
\text { Major incompatibility } \\
\text { Minor incompatibility } \\
\text { No incompatibility }\end{array}$ & $\begin{array}{l}14(23 \%) \\
13(21 \%) \\
35(57 \%)\end{array}$ \\
\hline $\begin{array}{l}\text { Sex matching } \\
\text { Matched } \\
\text { Unmatched } \\
\end{array}$ & $\begin{array}{l}31(50 \%) \\
31(50 \%)\end{array}$ \\
\hline $\begin{array}{l}\text { Acute GvHD } \\
\text { Grades 0-I } \\
\text { Grades II-IV }\end{array}$ & $\begin{array}{l}42(68 \%) \\
20(32 \%)\end{array}$ \\
\hline $\begin{array}{l}\text { Chronic GvHD } \\
\text { None } \\
\text { Mild } \\
\text { Moderate } \\
\text { Severe } \\
\text { Non evaluable** }\end{array}$ & $\begin{array}{l}37(60 \%) \\
11(18 \%) \\
9(15 \%) \\
3(5 \%) \\
2(3 \%)\end{array}$ \\
\hline $\begin{array}{l}\text { CMV reactivation } \\
\text { Yes } \\
\text { No }\end{array}$ & $\begin{array}{l}35(56 \%) \\
27(44 \%)\end{array}$ \\
\hline $\begin{array}{l}\text { Conditioning regimen } \\
\text { RIC (FMC) } \\
\text { Other*** }\end{array}$ & $\begin{array}{l}40(65 \%) \\
22(35 \%)\end{array}$ \\
\hline $\begin{array}{l}\text { Source of stem cells } \\
\text { Bone marrow } \\
\text { Peripheral blood }\end{array}$ & $\begin{array}{c}8(13 \%) \\
54(87 \%)\end{array}$ \\
\hline Median CD34 dose (x106/kg) (range) & $5.0(0.3-37.6)$ \\
\hline $\begin{array}{l}\text { T-cell depletion } \\
\text { Yes } \\
\text { No }\end{array}$ & $\begin{array}{c}57(92 \%) \\
5(8 \%)\end{array}$ \\
\hline
\end{tabular}

continued from the previous coloum

\begin{tabular}{lc} 
Poor graft function & \\
Primary & $21(34 \%)$ \\
Secondary & $41(66 \%)$ \\
\hline Chimerism pre-CD34+- infusion & \\
Donor & $21(34 \%)$ \\
Mixed & $32(52 \%)$ \\
Missing values & 9 \\
\hline
\end{tabular}

EBMT: European Group for Blood and Marrow Transplantation; HCT-Cl: Hematopoietic Cell Transplantation-specific Comorbidity Index; CMV cytomegalovirus; R/D: recipient/donor; GvHD: graft-versus-host disease; RIC: reduced intensity conditioning; FMC: fludarabine, melphalan, alematuzumab. *EBMT Risk Score: early disease stage includes acute leukemia (AL) transplanted in first complete remission (CR), myelodysplastic syndrome (MDS) transplanted untreated or in first $\mathrm{CR}$; intermediate disease stage includes $\mathrm{AL}$ in second $\mathrm{CR}$, chronic myeloid leukemia (CML) in all other stages than first chronic phase or blast crisis, MDS in second CR or in partial remission (PR), lymphoma and multiple myeloma in second CR, in PR or stable disease; late disease stage includes AL in all other disease stages, CML in blast crisis, MDS in all other disease stages and lymphoma and multiple myeloma in all disease stages other than those defined as early or intermediate. Stage is not applicable for aplastic anemia, primary immunodeficiencies and sickle cell disease **Patients died within 100 days after allogeneic stem cell transplantation. *** Conditioning regimen (other): Campath $1 \mathrm{H} /$ thiotepa/total body irradiation (TBI) $(\mathrm{n}=1)$; Campath 1H/cyclophosphamide/TBI $(\mathrm{n}=2)$; Campath $1 \mathrm{H} /$ fluradabine/ cyclophosphamide/TBI ( $\mathrm{n}=1) ;$ cyclophosphamide/TBI ( $\mathrm{n}=3)$; fluradabine/ cyclophosphamide/TBI ( $\mathrm{n}=3$ ); Campath 1H/BEAM (carmustine, etoposide, cytarabine, melphalan) $(n=5)$; fluradabine/thiotepa $(n=1)$; Campath $1 \mathrm{H} /$ fluradabine/busulfan $(\mathrm{n}=2)$; Campath $1 \mathrm{H} /$ fluradabine/treosulfan $(\mathrm{n}=1)$; Campath $1 \mathrm{H} /$ cyclophosphamide $(n=1)$; antithymocyte globulin/fluradabine/busulfan $(n=1)$; cyclophosphamide/ fluradabine/TBI $(\mathrm{n}=1)$

\section{Results}

\section{Primary and secondary poor graft function}

The overall incidence of poor graft function treated with CD34+-selected infusion was 3.1\% (62/1996) among the total population of patients transplanted. Twenty-one patients in this group (34\%) had primary poor graft function and 41 had secondary poor graft function (66\%). The median time from engraftment to the development of secondary poor graft function was 130 days (range, 5-2,694). Poor graft function was restricted to one or two hematopoietic cell lineages in 19 patients (31\%), and occurred in all three lineages in 43 patients $(69 \%)$, although patients with primary poor graft function were more likely to have trilineage cytopenia than those with secondary poor graft function (19 of 21 [91\%] versus 24 of $41[61 \%$, respectively; $P=0.01)$. In a multivariate analysis to determine factors associated with primary versus secondary poor graft function, a mismatched unrelated donor was associated with a higher probability of primary poor graft function $(P=0.03)$, whereas CMV serostatus other than negative for both recipient and donor was associated with a higher risk of secondary poor graft function $(P=0.008)$. No other significant associations for primary versus secondary poor graft function in the treated group were found for any of the following factors: donor-recipient sex matching, donor-recipient age, Hematopoietic Cell Transplantation-specific Comorbidity Index, European Group for Blood and Marrow Transplantation (EBMT) Risk Score, presence of GvHD, major ABO incompatibility or the original transplant $\mathrm{CD}_{3} 4^{+}$cell dose (Online Supplementary Tables S2 and S3).

\section{Hematologic improvement following CD34 ${ }^{+}$-selected infusion}

The median interval from allogeneic SCT to CD34+selected infusion was 15 months (range, 1-226); the medi- 
an $\mathrm{CD}_{3} 4^{+}$cell dose $/ \mathrm{kg}$ recipient weight was $3.2 \times 10^{6} / \mathrm{kg}$ (range, 0.47-14.2) and the median $\mathrm{CD}^{+}$dose was $4.3 \times 10^{3} / \mathrm{kg}$ (range, $0-13$ ). At the time of CD34+-selected infusion, the median neutrophil count was $0.7 \times 10^{\circ} / \mathrm{L}$ (range, $0.01-10$ ), the median platelet count was $17 \times 10^{9} / \mathrm{L}$ (range, 5-296) and the median hemoglobin concentration was $8.7 \mathrm{~g} / \mathrm{dL}$ (range, 5.3 to 12.5). Of the 62 treated patients, $47(76 \%)$ showed a hematologic improvement with complete $(n=39)$ or partial recovery $(n=8)$. Evidence of recovery was observed in 23 patients within 30 days; of these, 20 patients achieved complete recovery and three patients had partial recovery. Hematologic improvement after 30 days was observed in 23 patients; of these 18 patients achieved complete recovery and five patients had partial recovery. In patients showing hematologic improvement with complete or partial recovery, the median number of days required for the recovery of neutrophils was 29 days (range, 6-1,182), that for the recovery of platelets was 18 days (range, 5-600) and that for recovery of hemoglobin was 25 days (range, 6-511). The time range for recovery of neutrophils was especially prolonged and reflected the requirement for responding patients to be independent of any growth factor support. There were no differences in recovery times for patients showing complete versus partial recovery (Figure 1). The probability of complete or partial recovery was also analyzed according to the number of lineages affected and although there were no differences in total rates of recovery, the proportion of patients achieving complete recovery was greater if poor graft function affected one or two lineages versus all three lineages (16/16 [100\%] versus $23 / 31$ [74\%]; $P=0.04)$. All patients who demonstrated complete or partial recovery after $\mathrm{CD}_{34}{ }^{+}$-selected infusion maintained their recovery throughout the follow-up period.

\section{Factors associated with hematologic improvement}

In univariate analyses to determine factors predictive of recovery, we found that shared donor-recipient CMV seronegative status, donor-recipient sex matching, absence of active infection at the time of CD34+-selected infusion and low EBMT Risk Score were associated with recovery (Table $2 \mathrm{~A}, \mathrm{~B}$ ). Patients sharing a CMV seronegative status with the donor achieved complete or partial recovery more frequently than any other recipient-donor serostatus combination $(21 / 23$ [91\%] versus 26/39 [68\%]; $P=0.03)$. Sex matching between the donor and recipient was also associated with a better rate of recovery than mismatched combinations (28/31 [90\%] versus 19/31 [61\%]; $P=0.008) ;$ female recipients of transplants from male donors had the worst rates of recovery (8/15 [53\%] versus $39 / 47$ [83\%]; $P=0.02$ ). Patients without active infection during $\mathrm{CD}_{3} 4^{+}$-selected infusion had higher rates of recovery than the patients with infection (33/36 [92\%] versus $12 / 24$ [50\%]; $P<0.001$; data missing for 2 patients).
A

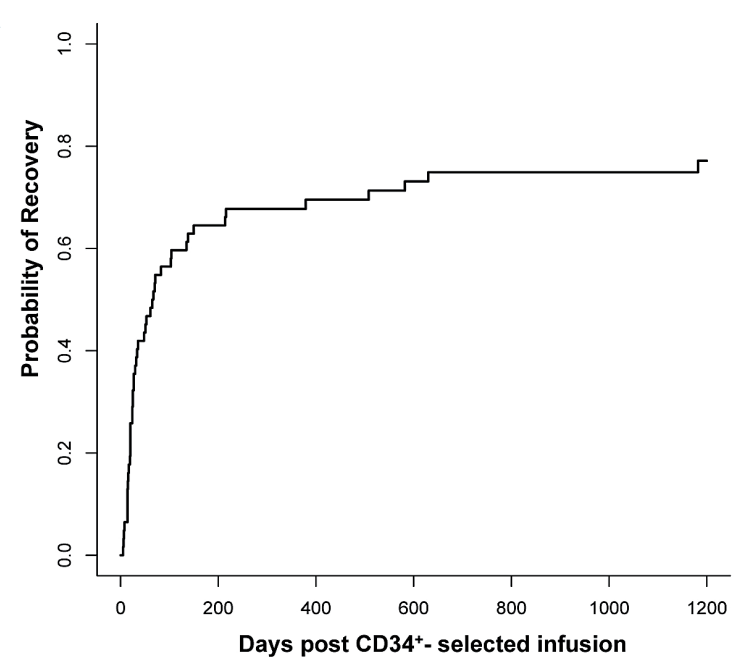

C

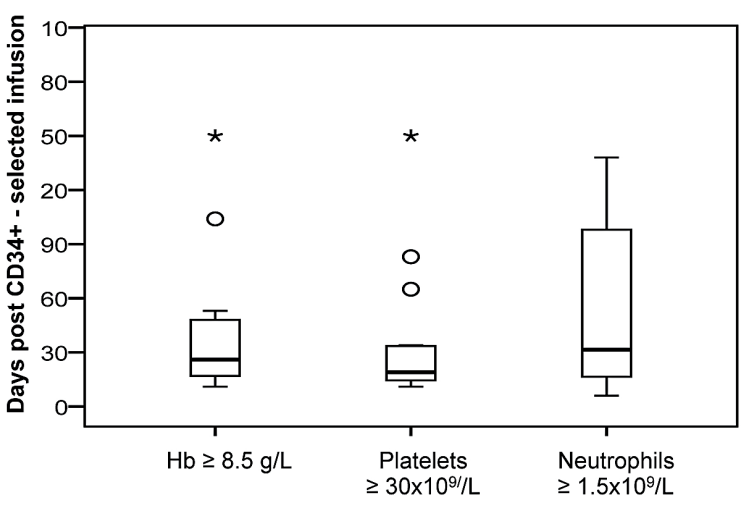

Cell Lineages (Hematologic Improvement)

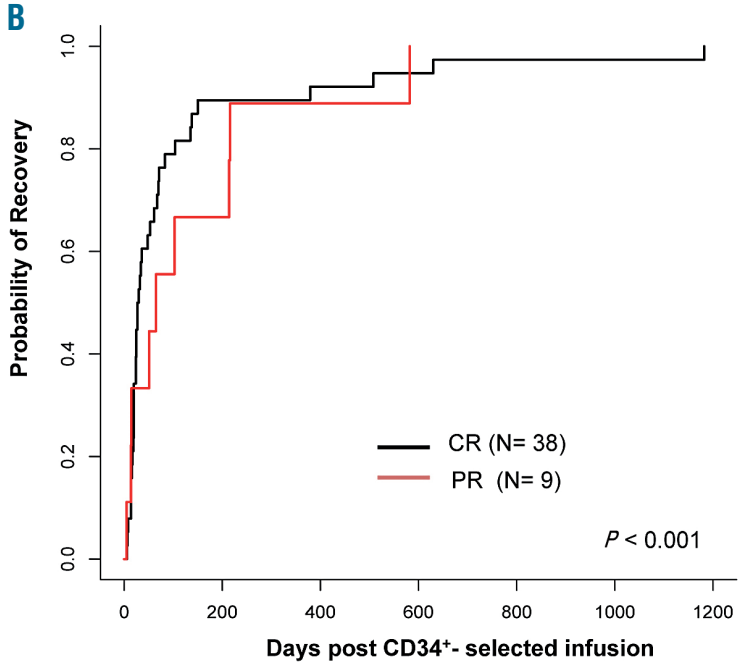

Figure 1. Time to recovery after $\mathrm{CD} 34^{+}$-selected stem cell infusion. (A) Time to recovery (days) for all patients. (B) Time to recovery (days) for patients with complete recovery and partial recovery. (C) Time to recovery (days) according to cell lineages. CR: complete recovery; PR: partial recovery; Hb: hemoglobin. 
Table 2A. Univariate analysis of pre-transplant variables as predictors of recovery after $\mathrm{CD} 34^{+}$-selected infusion.

\begin{tabular}{|c|c|c|c|}
\hline & $\mathbf{N}$ & Recovery, N (\%) & P-value \\
\hline $\begin{array}{l}\text { HCT-CI } \\
\text { Low risk } \\
\text { Intermediate risk } \\
\text { High risk }\end{array}$ & $\begin{array}{l}45 \\
15 \\
2\end{array}$ & $\begin{array}{l}35(78 \%) \\
11(73 \%) \\
1(50 \%)\end{array}$ & 0.6 \\
\hline $\begin{array}{l}\text { R/D sex } \\
\text { Unmatched } \\
\text { Matched }\end{array}$ & $\begin{array}{l}31 \\
31\end{array}$ & $\begin{array}{l}19(61 \%) \\
28(90 \%)\end{array}$ & 0.008 \\
\hline $\begin{array}{l}\text { Donor type } \\
\text { Related donor } \\
\text { Matched unrelated donor } \\
\text { Mismatched unrelated donor }\end{array}$ & $\begin{array}{l}28 \\
18 \\
16\end{array}$ & $\begin{array}{l}22(79 \%) \\
13(72 \%) \\
12(75 \%)\end{array}$ & 0.9 \\
\hline $\begin{array}{l}\text { ABO status } \\
\text { No incompatibility } \\
\text { Major incompatibility } \\
\text { Minor incompatibility }\end{array}$ & $\begin{array}{l}35 \\
14 \\
13\end{array}$ & $\begin{array}{c}28(80 \%) \\
10(71 \%) \\
9(69 \%)\end{array}$ & 0.7 \\
\hline $\begin{array}{l}\text { CMV status (R/D) } \\
\text { Other } \\
\text { Negative/negative }\end{array}$ & $\begin{array}{l}39 \\
23\end{array}$ & $\begin{array}{l}26(67 \%) \\
21(91 \%)\end{array}$ & 0.03 \\
\hline $\begin{array}{l}\text { EBMT Risk Score* } \\
\text { Early } \\
\text { Intermediate } \\
\text { Advanced } \\
\text { Non-malignant }\end{array}$ & $\begin{array}{c}19 \\
28 \\
9 \\
6\end{array}$ & $\begin{array}{l}15(79 \%) \\
25(89 \%) \\
4(44 \%) \\
3(50 \%)\end{array}$ & 0.02 \\
\hline $\begin{array}{l}\text { HCTCI: Hematopoietic Cell Transpla } \\
\text { ent/donor; CMV: cytomegalovirus; }, \\
\text { Transplantation. *EBMT Risk Score: } \\
\text { transplanted in first complete remissi } \\
\text { planted untreated or in first CR; interı } \\
\text { chronic myeloid leukemia (CML) in } \\
\text { crisis, MDS in second CR or in partial } \\
\text { ma in second CR,in PR or stable dise } \\
\text { ease stages, CML in blast crisis, MDS } \\
\text { multiple myeloma in all disease stage } \\
\text { ate.Stage is not applicable for aplastic } \\
\text { le cell disease. }\end{array}$ & & $\begin{array}{l}\text { ific Comorbidity II } \\
\text { ean Group for Blc } \\
\text { stage includes acu } \\
\text { elodysplastic syndr } \\
\text { ease stage includes } \\
\text { ges than first chror } \\
\text { PR), lymphoma an } \\
\text { ase stage includes } \\
\text { disease stages an } \\
\text { those defined as e } \\
\text { mary immunodefi }\end{array}$ & $\begin{array}{l}\text { x; R/D: recipi- } \\
\text { and Marrow } \\
\text { eukemia (AL) } \\
\text { (MDS) trans- } \\
\text { in second CR, } \\
\text { hase or blast } \\
\text { ultiple myelo- } \\
\text { h all other dis- } \\
\text { mphoma and } \\
\text { or intermedi- } \\
\text { cies and sick- }\end{array}$ \\
\hline
\end{tabular}

Finally, patients with early or intermediate stage disease had better recovery rates than patients with advanced disease (15/19 [79\%] and 25/28 [89\%] versus 4/9 (44\%), respectively; $P=0.02)$. In multivariate analysis, only $\mathrm{CMV}$ serostatus, recipient-donor sex matching and infection remained statistically significant (Table 3). The type of poor graft function (primary or secondary), type of donor (related, matched or mismatched unrelated donor), $\mathrm{ABO}$ incompatibility, patient's age, previous or active acute or chronic GvHD, CD34+ and $\mathrm{CD}^{+}$cell dose of the top-up infusion, CMV reactivation, full versus mixed donor chimerism and the interval from the initial allogeneic SCT to $\mathrm{CD}_{34}{ }^{+}$-selected infusion had no impact on the achievement of complete or partial recovery (Table 2A, B). Chimerism status (available for $87 \%$ of patients in the 60 days prior to infusion) categorized into full donor or mixed chimerism also did not predict response. A subset of six patients with mixed chimerism received co-infusion of $\mathrm{T}$ cells at the time of $\mathrm{CD} 34^{+}$-selected top-up. The cotransfer of donor $\mathrm{T}$ cells had no impact on recovery $(5 / 6$ [83\%] who received co-infusion of $\mathrm{T}$ cells versus $16 / 22$ $[73 \%]$ who did not receive $\mathrm{T}$ cells showed complete or partial recovery; $P=0.6$ ).

\section{Cytomegalovirus serostatus as a predictor of recovery}

CMV monitoring by polymerase chain reaction was performed twice a week for the first 3 months and surveil-
Table 2B. Univariate analysis of post-transplant variables as predictors of recovery after $\mathrm{CD}_{3} 4^{+}$-selected infusion.

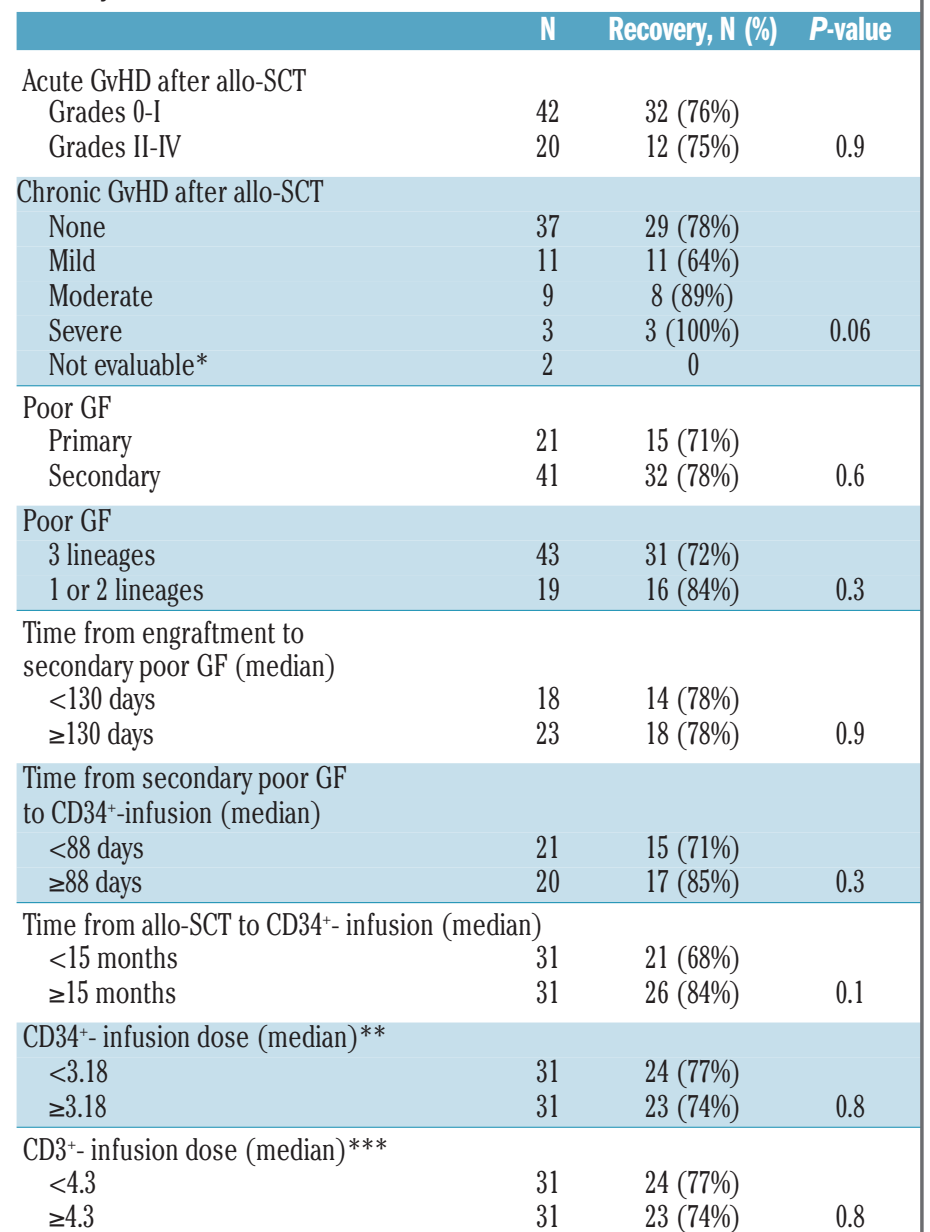

Addition of T cells at the time

of CD34+ infusion

Addition and mixed donor chimerism $\quad 6 \quad 5(83 \%)$

No addition and mixed donor chimerism $\quad 25 \quad 16(73 \%)$

Missing values

9

Recipient age at CD34+- infusion (median)

Age $<50$ years

Age $\geq 50$ years

$31 \quad 22(71 \%)$

$31 \quad 25(81 \%)$

0.4

Donor age at CD34+-infusion (median)

Age $<39$ years

Age $\geq 39$ years

$29 \quad 25(86 \%)$

0.07

Active infection at the time of CD34+- infusion

Yes
No
Missing values

GvHD (acute/chronic) at the time of CD34+- infusion

$\begin{array}{lccc}\text { Yes } & 15 & 10(67 \%) & \\ \text { No } & 46 & 36(78 \%) & 0.4 \\ \text { Missing values } & 1 & & \end{array}$

Immunosuppression at the time of CD34+- infusion

$\begin{array}{llll}\text { Yes } & 39 & 29(74 \%) & \\ \text { No } & 23 & 18(78 \%) & 0.7\end{array}$

Chimerism before CD34+- infusion

$\begin{array}{lccc}\text { Donor } & 21 & 17(81 \%) & \\ \text { Mixed } & 32 & 25(78 \%) & 0.8 \\ \text { Missing values } & 9 & & \end{array}$

GvHD: graft-versus-host disease; allo-SCT: allogeneic stem cell transplantation; GF: graft function. *Patients died within 100 days after allo-SCT. ${ }^{* *}$ Cell dose $\times 10^{6} / \mathrm{kg}$ recipient weigh $* * *$ Cell dose $\times 10^{3} / \mathrm{kg}$ recipient weight. 
lance continued in a subset of patients at risk of late reactivation (e.g., patients with GvHD, prior multiple reactivations). Twenty-three recipients shared a CMV seronegative status with the donor and did not have CMV reactivation. Of the remaining 39 patients, 35 (92\%) had $\mathrm{CMV}$ re-activation before the CD34+-selected infusion. No patients had CMV re-activation following infusion. The relationship between complete or partial recovery and CMV serostatus correlated with CMV re-activation, with $23 / 35$ (66\%) of patients who had CMV re-activation showing a response versus $24 / 27$ (89\%) of those who did not have CMV re-activation $(P=0.04)$. However, other variables related to the severity of CMV infection including earlier re-activation, higher peak CMV viremia, longer duration of antiviral drug treatment, higher number of CMV re-activations, active CMV infection at the time of infusion and CMV disease did not correlate with worse recovery (Online Supplementary Table S4).

Table 3. Multivariate analysis for recovery after CD34+- selected infusion.

\begin{tabular}{lccc} 
& N & OR (95\% Cl) & P-value \\
Active infection at the time of & & & \\
CD34 ${ }^{-}$-selected infusion & & & \\
$\quad$ Yes & 24 & 1.0 & \\
$\quad$ No & 36 & $38.9(3.9-388.3)$ & 0.002 \\
$\quad$ Missing values & 2 & & \\
RD CMV status & & & \\
$\quad$ Other & 37 & 1.0 & \\
$\quad$ Negative/negative & 23 & $16.8(1.4-195.8)$ & 0.02 \\
$\quad$ Missing values & 2 & & \\
R/D sex & & & \\
$\quad$ Unmatched & 31 & 1.0 & \\
$\quad$ Matched & 29 & $24.4(2.3-254.5)$ & 0.008 \\
$\quad$ Missing values & 2 & & \\
\hline
\end{tabular}

R/D: recipient/donor; CMV: cytomegalovirus.

\section{Graft-versus-host disease}

Acute GvHD following $\mathrm{CD}_{3} 4^{+}$- selected infusion occurred in a total of seven patients $(11 \%)$ at a median of 15 days (range, 7-26 days; 3 patients had acute GvHD grade I-II and 4 patients had grade III-IV).

Chronic GvHD was seen in five patients (8\%) who survived for more than 100 days following CD34+-selected infusion (1 patient had mild, 1 had moderate and 3 had severe chronic GvHD). Of the six patients who received co-transfer of donor T cells, two developed acute GvHD grade III-IV and two developed mild and severe chronic GvHD.

\section{Survival}

At a median follow up of 6.4 years (range, 2.8-9.9), 29 patients (11/15 non-responding [73\%], 7/8 with partial recovery [87\%] and 11/39 with complete recovery [28\%]) had died. The causes of death included infection (38\%), relapse $(34 \%)$, GvHD (16\%), secondary malignancies $(3 \%)$ and others $(9 \%)$. The median overall survival for all patients was 5.4 years $(95 \%$ confidence interval $[95 \% \mathrm{CI}]$ : 1.3-9.4). One and 5-year overall survival rates were $70 \%$ (95\% CI: 58-82) and 54\% (95\% CI: 41-68), respectively. In patients with complete recovery after CD $34^{+}$-selected infusion, the overall survival rates at 1 and 5 years were $86.7 \%$ (95\% CI: 76-98) and 74.4\% (95\% CI: 59-89), respectively, while those in patients with partial recovery were $62.5 \%$ (95\% CI: 28-97) and 16.7\% (95\% CI: 3-46) respectively. Patients showing no response had poor outcomes with overall survival rates of $33.3 \%$ (95\% CI: 9-58) and $22.2 \%(95 \% \mathrm{CI}: 5-47)$ at 1 and 5 years respectively (Figure 2A). Of the 15 patients who did not recover, three $(20 \%)$ remain alive: one patient had red cell aplasia and is currently on periodic red cell transfusions with iron chelation; a second patient underwent second allogeneic SCT; and the third patient with trilineage poor graft function is requiring ongoing transfusional support and growth factors. The remaining patients without response died, pri-
A

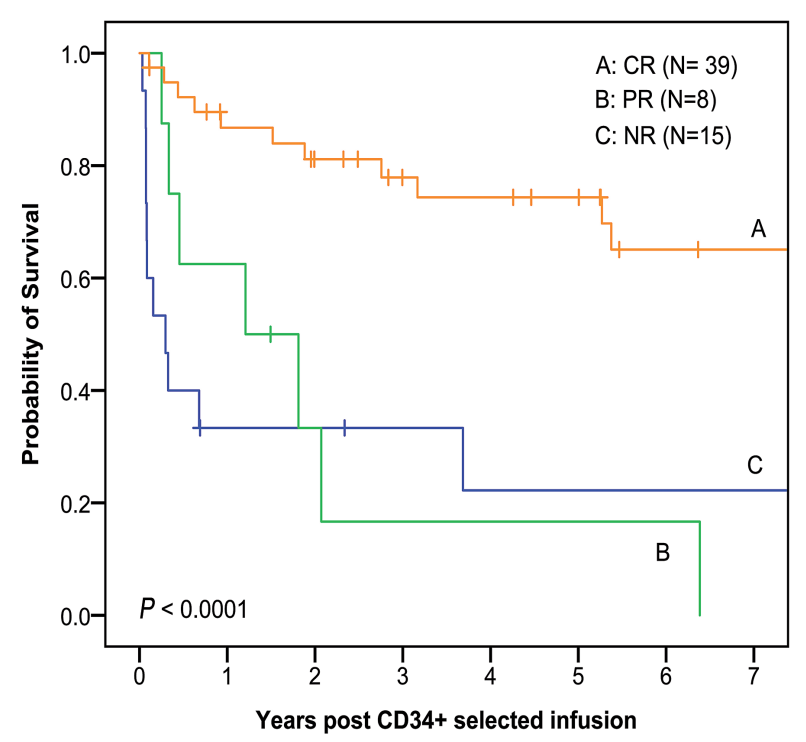

B

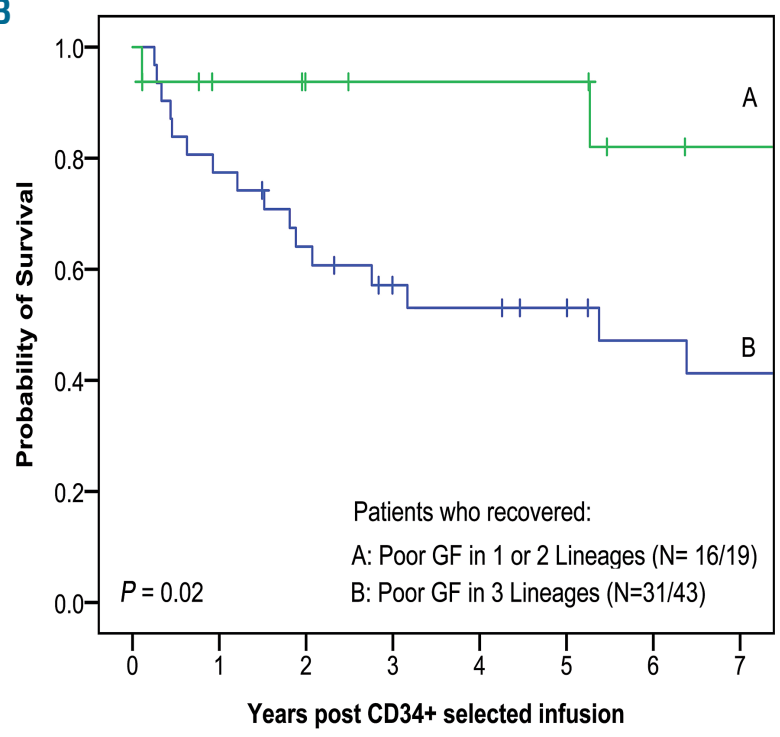

Figure 2. Kaplan-Meier estimate of overall survival after CD34+-selected stem cell infusion. (A) Survival curves according to type of recovery; complete, partial or no recovery. (B) Survival curves in patients who recovered after $\mathrm{CD} 34^{+}$-selected infusion, according to whether they had poor graft function in one or two lineages or poor graft function in all three lineages. CR: complete recovery; PR: partial recovery; NR: no recovery. 
marily as a result of infectious complications. Of the patients who showed blood count recovery, those who initially had poor graft function in one or two lineages had a superior 5-year overall survival rate of $93.8 \%$ (95\% CI: 82-99) compared to those with trilineage poor graft function who had a 5 -year overall survival rate of $53 \%(95 \%$ CI: 34-88) (Figure 2B). The rates or completeness of recovery together with their effect upon outcome were similar over time, as identified by comparing patient cohorts receiving $\mathrm{CD} 34^{+}$-selected infusions in the early versus late time periods (2000-2009 versus 2010-2018) of the study (data not shown).

\section{Discussion}

Poor graft function occurs only in a minority of patients following allogeneic SCT but is associated with a high mortality. Management of such patients is resource-intensive with patients requiring multiple hospital visits or prolonged, inpatient admissions. Our study shows that the majority of patients with poor graft function who are given $\mathrm{CD} 34^{+}$-selected infusion without conditioning will subsequently have a hematologic improvement; in more than six of ten patients, the recovery will be permanent and complete, avoiding the need for transfusion or growth factor support. The procedure is safe with low rates of acute and chronic GvHD, consistent with the low doses of $\mathrm{T}$ cells contained within the CD $34^{+}$-selected graft. Our report does, however, highlight that there are subgroups of patients (those with recipient or donor CMV seropositivity, with active infection or with recipient-donor sex mismatching), who respond less favorably and for whom alternative strategies may be required.

Our study differs from other studies that employed CD34+-selected infusion only in patients with full donor chimerism. Reflecting the use of T-cell depletion in 91\% of patients in our series, mixed chimerism was evident in $58 \%$ of recipients (affecting the T-cell lineage in all patients with or without involvement of B-and/or myeloid-lineages), with none of these patients having evidence of disease relapse. Our data confirm that the approach of $\mathrm{CD}_{3} 4^{+}$-selected infusion is feasible in such patients with recovery rates similar to those of patients with full donor chimerism. Although a small subset of patients with mixed chimerism received a fixed dose of $T$ cells at the time of $\mathrm{CD}_{3} 4^{+}$-selected infusion, this had no effect upon outcome. To avoid the additional risk of $\mathrm{GvHD}$, we do not routinely give additional $\mathrm{T}$ cells in this setting. We were unable to test whether the precise level of donor chimerism correlated with recovery because the analysis methods used to detect chimerism were only semi-quantitative at the time most patients were treated.

The main limitation of our analysis is the lack of a control group so that it is difficult to measure the effect of the CD34 $4^{+}$-selected infusion versus the effect of other hematopoietic stem cell (HSC)-intrinsic or -extrinsic factors that lead to eventual recovery. The lack of a control group is particularly relevant to the observed kinetics of recovery with about one in two patients recovering more than 30 days following infusion (although most achieved complete or partial recovery within 3 months). We observed similar kinetics of recovery to those observed by other groups using $\mathrm{CD} 34^{+}$-selected infusion without preconditioning. ${ }^{7-11}$ We currently lack a clear framework in human patients for understanding how niche function and availability found in patients with poor graft function influence the re-populating capacity of infused $\mathrm{CD}_{3} 4^{+}$ selected cells. While we presume that there are too few endogenous HSC to outcompete the infused HSC in patients with poor graft function, the number of available niches in this clinical setting is unknown and likely to be influenced by multiple factors including prior therapies, host-pathogen interactions and immune dysregulation.

The larger number of patients in this series compared to the numbers in other reports afforded us the opportunity to explore predictors of response in more detail. We found that active infection (identified using the surrogate of antimicrobial therapy) at the time of $\mathrm{CD}_{3} 4^{+}$-selected infusion was the strongest negative predictor of recovery. Of note, lack of recovery was not related to the level of neutropenia, a finding that is indicative that other factors independent of the overall severity of poor graft function may prevent a response (data not shown). Under conditions of replicative stress (e.g., allogeneic SCT) chronic inflammatory signals such as those mediated through Toll-like receptors or pro-inflammatory cytokines (e.g., tumor necrosis factor- $\alpha$, interferon- $\gamma$ or interleukin-1) impair HSC self-renewal through induction of apoptosis or by driving myeloid differentiation. ${ }^{17}$ In humans, similar mechanisms have been invoked for bone marrow failure in the context of chronic infections. Thus, one possibility is that the pro-inflammatory conditions provoked by infection pose a significant barrier to establishing a functional HSC pool from infused CD34+-selected cells.

Although the infections in this cohort of patients were heterogeneous, CMV infection had the most noticeable impact on the response to $\mathrm{CD} 34^{+}$-selected infusion. Both CMV seropositivity in the donor and/or recipient and a history of CMV re-activation predicted a worse recovery although the majority of patients in both groups achieved complete or partial recovery. We had reasoned that recovery would correlate inversely with surrogates of more severe infections (e.g., high peak CMV viremia or greater numbers of re-activations) but this was not the case; these data suggest that either the sample size of our cohort was not sufficiently powered to detect a relationship or that other mechanisms are involved. While the myelosuppressive effects of anti-CMV drugs are well described, CMV infection may also impair niche functions and HSC selfrenewal by directly infecting bone marrow macrophages and stroma, or indirectly as a consequence of chronic inflammation. ${ }^{18}$ Currently, it is difficult to conceive new strategies to overcome these issues other than accelerating restoration of anti-CMV immunity through adoptive transfer of CMV-specific or memory $T$ cells, or the use of anti-CMV drugs that cause less myelosuppression (e.g., letermovir). It will be of interest, therefore, to evaluate how the introduction of CMV prophylaxis with letermovir affects the overall incidence of poor graft function and responses to $\mathrm{CD} 34^{+}$-selected infusions. In our view, CMV-seropositive patients or those with CMV re-activation should not be excluded from consideration for CD34+-selected infusion; however, this approach should be considered as part of a broader plan to improve immune reconstitution and avoid excess use of drugs that are toxic to the bone marrow.

Sex matching between the donor and recipient also influenced recovery following $\mathrm{CD} 34^{+}$-selected infusions, specifically when the transplant was from a male donor 
into a female recipient. This finding was unexpected because female recipients of male grafts had either full donor chimerism or stable mixed chimerism prior to CD34+-selected infusion (6/14 [30\%] full donor and 8/14 [57\%] stable mixed chimerism). This finding would be consistent with the concept of 'split tolerance' identified in animal models in which hematopoietic chimeras with mixed T-cell chimerism can nevertheless reject other donor tissues, including other hematopoietic cells. ${ }^{19}$ It will therefore be important to track for evidence of anti-HY antibodies and HY-specific cytotoxic T lymphocytes either prior to or following infusion of male grafts into female recipients. Potential strategies that could be considered in future trials would be the use of nonmyeloablative conditioning prior to $\mathrm{CD} 34^{+}$-selected infusion, or the cotransfer of regulatory $\mathrm{T}$ cells $;^{20}$ in the latter case, the regulatory $\mathrm{T}$ cells may be particularly important in providing immune privileged sites for HSC within the bone marrow. ${ }^{21}$

The minority of patients showing no recovery or only partial recovery following CD34+-selected infusion had worse overall survival, mostly explained by non-relapse deaths in the first 18 months following treatment (12/14 [86\%] of patients with no or partial recovery died due to non-relapse causes, in the first 18 months). It will be crucial to implement alternative strategies in such patients including a second allogeneic SCT; in this case, use of the same donor can afford the opportunity to use less toxic regimens, even though these procedures still carry a high risk in patients who may have accumulated additional problems such as infection.

In conclusion, we confirm that CD34+-selected donor infusion without conditioning is an important therapeutic option that should be considered in patients with poor graft function following allogeneic SCT. Our findings also indicate that this approach can be applied in patients with stable mixed chimerism, a group excluded from previous studies. The low risk of the procedure means that this strategy can be adopted even in patients with risk factors for lower rates of recovery (e.g., in patients with active infection, of whom 1 in 2 patients will still respond). However, the overall heterogeneity of response is indicative that multiple factors (both intrinsic and extrinsic) influence graft integrity and highlight the critical need for further investigation of mechanisms underlying poor graft function. The information gained could be used to define the role of emerging treatments such as thrombopoietinreceptor agonists, ${ }^{22}$ which are the subject of ongoing trials. In the future, trials investigating combination therapies involving CD $34^{+}$-selected infusion and co-transfer of mesenchymal cells to improve niche function ${ }^{23}$ or regulatory $\mathrm{T}$ cells to augment immune tolerance of transferred HSC should be conducted.

\section{References}

1. Olsson R, Remberger M, Schaffer M, et al. Graft failure in the modern era of allogeneic hematopoietic SCT. Bone Marrow Transplant. 2013;48(4):537-543.

2. Rondón G, Saliba RM, Khouri I, et al. Longterm follow-up of patients who experienced graft failure postallogeneic progenitor cell transplantation. Results of a single institution analysis. Biol Blood Marrow Transplant. 2008;14(8):859-866.

3. Cluzeau T, Lambert J, Raus N, et al. Risk factors and outcome of graft failure after HLA matched and mismatched unrelated donor hematopoietic stem cell transplantation: a study on behalf of SFGM-TC and SFHI. Bone Marrow Transplant. 2016;51(5):687691.

4. Lee KH, Lee JH, Choi SJ, et al. Failure of trilineage blood cell reconstitution after initial neutrophil engraftment in patients undergoing allogeneic hematopoietic cell transplantation - frequency and outcomes. Bone Marrow Transplant. 2004;33(7):729-734.

5. Masouridi-Levrat S, Simonetta F, Chalandon $Y$. Immunological basis of bone marrow failure after allogeneic hematopoietic stem cell transplantation. Front Immunol. 2016;7: 362.

6. Ferrà C, Sanz J, Morgades M, et al. Outcome of graft failure after allogeneic stem cell transplant: study of 89 patients. Leuk Lymphoma. 2015;56(3):656-662.

7. Larocca A, Piaggio G, Podestà M, et al. Boost of CD34+-selected peripheral blood cells without further conditioning in patients with poor graft function following allogeneic stem cell transplantation. Haematologica. 2006;91(7):935-940.

8. Askaa B, Fischer-Nielsen A, Vindeløv L, et al.
Treatment of poor graft function after allogeneic hematopoietic cell transplantation with a booster of CD34-selected cells infused without conditioning. Bone Marrow Transplant. 2014;49(5):720-721.

9. Klyuchnikov E, El-Cheikh J, Sputtek A, et al. CD34+-selected stem cell boost without further conditioning for poor graft function after allogeneic stem cell transplantation in patients with hematological malignancies. Biol Blood Marrow Transplant. 2014;20(3): 382-386.

10. Stasia A, Ghiso A, Galaverna F, et al. CD34 selected cells for the treatment of poor graft function after allogeneic stem cell transplantation. Biol Blood Marrow Transplant. 2014;20(9):1440-1443.

11. Ghobadi A, Fiala MA, Ramsingh $G$, et al Fresh or cryopreserved CD34+-selected mobilized peripheral blood stem and progenitor cells for the treatment of poor graft function after allogeneic hematopoietic cell transplantation. Biol Blood Marrow Transplant. 2017;23(7):1072-1077.

12. Glucksberg H, Storb R, Fefer A, et al. Clinical manifestations of graft-verus-host disease in human repicients of marrow from HLAmatched sibling donors. Transplantation. 1974;18(4):295-304

13. Jagasia $\mathrm{MH}$, Greinix HT, Arora $M$, et al National institutes of health consensus development project on criteria for clinical trials in chronic graft-versus-host disease: I. The 2014 diagnosis and staging working group report. Biol Blood Marrow Transplant. 2015;21(3):389-401.

14. Kottaridis P, Milligan D, Chopra R, et al. In vivo CAMPATH-1H prevents graft-versushost disease following nonmyeloablative stem cell transplantation. Blood. 2000;96(7): 2419-2425.
15. Ings SJ, Balsa C, Mackinnon S, et al Peripheral blood stem cell yield in 400 normal donors mobilised with granulocyte colony-stimulating factor (G-CSF): impact of age, sex, donor weight and type of G-CSF used. Br J Haematol. 2006;134(5):517-525.

16. R Core Team (2014). R: A language and environment for statistical computing. $R$ Foundation for statistical computing, Vienna, Austria. URL http://www.R-project.org/.

17. Pietras EM. Inflammation: a key regulator of hematopoietic stem cell fate in health and disease. Blood. 2017;130(15):1693-1698.

18. Reddehase MJ. Mutual interference between cytomegalovirus and reconstitution of protective immunity after hematopoietic cell transplantation. Front Immunol. 2016;7:294

19. Al-Adra DP, Anderson CC. Mixed chimerism and split tolerance: mechanisms and clinical correlations. Chimerism. 2011;2 (4):89-101.

20. Pilat N, Granofszky N, Wekerle I. Combining adoptive $\mathrm{T}$ reg transfer with bone marrow transplantation for transplantation tolerance. Curr Transplant Rep. 2017;4(4):253-261.

21. Fujisaki J, Wu J, Carlson $\mathrm{AL}$, et al. In vivo imaging of $\mathrm{T}$ reg cells providing immune privilege to the haematopoietic stem-cell niche. Nature. 2011;474(7350):216-219.

22. Tang C, Chen F, Kong D, et al. Successful treatment of secondary poor graft function post allogeneic hematopoietic stem cell transplantation with eltrombopag. J Hematol Oncol. 2018;11(1):103.

23. Zhao K, Liu Q. The clinical application of mesenchymal stromal cells in hematopoietic stem cell transplantation. J Hematol Oncol. 2016;9(1):46. 